\title{
miR-23a-3p regulates the proliferation and apoptosis of human lens epithelial cells by targeting Bcl-2 in an in vitro model of cataracts
}

\author{
PENGXIANG YAO ${ }^{1}$, JIAN JIANG ${ }^{2}$, XIAOPING MA ${ }^{1}$, ZHENZHONG CHEN $^{1}$, YUFANG HONG ${ }^{1}$ and YANG WU $^{1}$ \\ ${ }^{1}$ Department of Ophthalmology, Zhongshan Hospital Xiamen Branch, Fudan University, Xiamen, Fujian 361000; \\ ${ }^{2}$ Department of Ophthalmology, Xiangya Hospital, Central South University, Changsha, Hunan 410000, P.R. China
}

Received July 29, 2020; Accepted November 6, 2020

DOI: $10.3892 /$ etm.2021.9853

\begin{abstract}
Cataracts account for $\sim 50 \%$ of the cases of blindness in individuals worldwide. The apoptosis of lens epithelial cells (LECs) occurs during the formation of cataracts, which is a non-congenital condition. Numerous microRNAs (miRs) have been reported to regulate apoptosis in LECs. For instance, miR-23a expression levels were shown to be upregulated in cataractous lenses; however, the function of miR-23a in cataracts remains undetermined. To establish an in vitro model of cataracts, human LECs, HLE-B3 cells, were induced with $200 \mu \mathrm{mol} / 1 \mathrm{H}_{2} \mathrm{O}_{2}$ for $24 \mathrm{~h}$. HLE-B3 cells were transfected with the miR-negative control (NC) mimic, miR-23a-3p mimic, miR-NC inhibitor, miR-23a-3p inhibitor, small interfering RNA (siRNA) targeting BCL2 (siRNA-BCL2) and siRNA-NC. The expression levels of miR-23a-3p were detected using reverse transcription-quantitative PCR. The interaction between miR-23a-3p and the 3'-untranslated region (UTR) of the target mRNA BCL2 was predicted by TargetScan 7.1, and further validated using a dual luciferase reporter assay. The BCL2 protein expression levels were analyzed using western blotting, cell proliferation was determined using a CCK-8 assay and the levels of cell apoptosis were analyzed using flow cytometric analysis. The results of the present study revealed that the expression levels of miR-23a-3p were significantly upregulated, while the expression levels of BCL2 were significantly downregulated in $\mathrm{H}_{2} \mathrm{O}_{2}$-induced HLE-B3 cells compared to untreated control cells. BCL2 was shown to be a target of miR-23a-3p. The miR-23a-3p inhibitor subsequently attenuated $\mathrm{H}_{2} \mathrm{O}_{2}$-induced apoptosis and increased the proliferation of HLE-B3 cells, which
\end{abstract}

Correspondence to: Dr Pengxiang Yao, Department of Ophthalmology, Zhongshan Hospital Xiamen Branch, Fudan University, 668 Jinhu Road, Xiamen, Fujian 361000, P.R. China E-mail: yaopengxiangzsh@yeah.net

Key words: cataracts, apoptosis, lens epithelial cells, proliferation, microRNA-23a-3p, Bcl-2 was partially reversed by siRNA-BCL2. In conclusion, the findings of the current study suggested that the inhibition of miR-23a-3p may attenuate $\mathrm{H}_{2} \mathrm{O}_{2}$-induced cataract formation by targeting BCL2, thus providing a novel therapeutic target for the treatment of patients with cataracts in the clinic.

\section{Introduction}

Cataracts have a high morbidity rate worldwide $(1,2)$ and account for $\sim 47.8 \%$ of the cases of blindness in individuals (3). Various factors result in the formation of cataracts, including age, diabetes and ultraviolet light exposure, with aging remaining the primary risk factor for cataract formation (4). For instance, age-related cataracts affect $46 \%$ of individuals with visual impairment (5-7). Therefore, it remains a priority to identify effective therapeutic targets for the treatment of cataracts to decrease the incidence of cataracts and blindness.

Currently, apoptosis has become a research hotspot in the area of ophthalmology. As the lens develops during the morphogenesis process, apoptosis serves as an important determinant for sustaining the normal conditions in the lens (8). The induction or reduction of apoptosis, due to genetic manipulation/mutations and/or environmental factors, has been shown to generate abnormal lenses or result in the absence of the ocular lens (9). In humans and animals, the presence of apoptosis in LECs has been identified to be frequently involved in the development of cataracts, which is a non-congenital condition (10).

MicroRNAs (miRNAs/miRs) are a subgroup of small non-coding RNAs of 20-25 nucleotides in length, which control post-transcriptional gene expression (11). miRNAs regulate the translation or degradation of target mRNAs by complementary binding to the 3'-untranslated region (UTR) of their target genes (12). miRNAs have been shown to serve roles in cell proliferation, apoptosis and differentiation (13). Numerous miRNAs have been reported to regulate the apoptosis of LECs in cataracts. For example, miR-221 induced LEC apoptosis by targeting sirtuin 1 (SIRT1) and transcription factor E2F3 (14), and miR-23b-3p promoted LEC apoptosis and autophagy by targeting SIRT1 (15). In addition, the expression levels of miR-23a were demonstrated to be upregulated in cataractous lenses (16). However, to the best of our knowledge, whether 
miR-23a-3p targets mRNAs in cataracts remains unknown. Therefore, determining the role of miR-23a-3p may provide a potential therapeutic target for the treatment of patients with cataracts.

\section{Materials and methods}

Cell culture. HLE-B3 cells were obtained from the American Type Culture Collection. HLE-B3 cells were cultured in minimum essential medium (Gibco; Thermo Fisher Scientific, Inc.) supplemented with 10\% FBS (Gibco; Thermo Fisher Scientific, Inc.) and $1 \%$ penicillin/streptomycin, and maintained in a humidified incubator with $5 \% \mathrm{CO}_{2}$ at $37^{\circ} \mathrm{C}$.

Oxidants induce cell apoptosis and trigger the development of cataracts (10). As peroxidative damage is mediated by the toxic metabolites of oxygen, such as hydroxide, $\mathrm{H}_{2} \mathrm{O}_{2}$ is frequently used to induce the apoptosis of LECs in vitro. For the establishment of an in vitro cataract model, HLE-B3 cells $\left(1 \times 10^{6}\right.$ cells/well $)$ were seeded into 6-well plates and induced at $37^{\circ} \mathrm{C}$ with $200 \mu \mathrm{mol} / 1 \mathrm{H}_{2} \mathrm{O}_{2}$ (Sigma-Aldrich; Merck KGaA) for $24 \mathrm{~h}$, as previously described $(17,18)$, while cells in control group were untreated.

Cell transfection. The miR-negative control (NC) mimic, miR-23a-3p mimic, miR-NC inhibitor and miR-23a-3p inhibitor, in addition to small interfering RNA (siRNA) targeting BCL2 (siRNA-BCL2) and siRNA-NC, were all synthesized by Shanghai GenePharma Co., Ltd. The $50 \mathrm{nM}$ miR-23a-3p mimic (5'-CCUUUAGGGACCGUUACA CUA-3') or $100 \mathrm{nM}$ miR-23a-3p inhibitor (5'-UAGUGUAAC GGUCCCUAAAGG-3') and their respective NCs (miR-NC mimic, 5'-CGAGCUCACUGGACAACGCCG-3' and miR-NC inhibitor, 5'-AGCUUAAGACAUUCCGAGGAAU-3') were transiently transfected into HLE-B3 cells using Lipofectamine ${ }^{\circledR}$ RNAiMAX reagent (Invitrogen; Thermo Fisher Scientific, Inc.), after incubation at $37^{\circ} \mathrm{C}$ for $48 \mathrm{~h}$, cells were collected for the subsequent experimentation. For the transient transfection of $50 \mathrm{nM}$ siRNA-NC (anti-sense, 5'-UGAGACAAUGCA UGCAGUACGG-3', sense, 5'-AUCGCAACAUAGACAGCU AACAG-3') and siRNA-BCL2 (anti-sense, 5'-UUCACAUUU AUAAACUAUUUGU-3', sense, 5'-AACAAAUAGUUUAUA AAUGUGAA-3') into HLE-B3 cells, Lipofectamine 2000 reagent (Invitrogen; Thermo Fisher Scientific, Inc.) was used, after incubation at $37^{\circ} \mathrm{C}$ for $48 \mathrm{~h}$, cells were collected for the subsequent experimentation.

Cell treatment. Briefly, control or transiently transfected HLE-B3 cells were seeded $\left(1 \times 10^{6}\right.$ cells/well) in 6-well plates and incubated overnight at $37^{\circ} \mathrm{C}$. Following which, HLE-B3 cells were treated with or without $200 \mu \mathrm{mol} / 1 \mathrm{H}_{2} \mathrm{O}_{2}$ for $24 \mathrm{~h}$ at $37^{\circ} \mathrm{C}$ before the conduction of the subsequent experiments.

Dual luciferase reporter assay. Using the online software TargetScan 7.1 (www.targetscan.org/vert_71/), it was found that miR-23a-3p was complementary to BCL2. The wild-type (WT) or mutant (MUT) BCL2 3'-UTR containing the binding site for miR-23a-3p was cloned into a pGL3 plasmid (Promega Corporation). The miR-23a-3p mimic or miR-NC mimic were co-transfected with pGL3-WT-BCL2 or pGL3-MUT-BCL2 into HLE-B3 cells using Lipofectamine ${ }^{\circledR} 2000$ reagent
(Invitrogen; Thermo Fisher Scientific, Inc.). After incubation at $37^{\circ} \mathrm{C}$ for $48 \mathrm{~h}$, cells were collected. Luciferase activity was measured using a dual-luciferase reporter assay system (Promega Corporation) normalized to Renilla luciferase activity in each group.

Cell proliferation assay. HLE-B3 cells were seeded into a 96-well plate and incubated overnight as aforementioned. Subsequently, $10 \mu 1$ Cell Counting Kit-8 (CCK-8) reagent (Dojindo Molecular Technologies, Inc.) was added to the HLE-B3 cells and incubated for $4 \mathrm{~h}$. The cell proliferation was measured at an absorbance of $450 \mathrm{~nm}$ using a microplate reader (BioTek Instruments, Inc.).

Flow cytometric analysis of apoptosis. HLE-B3 cell apoptosis was analyzed using an Annexin V-FITC/propidium iodide (PI) apoptosis detection kit (BD Biosciences). Briefly, $1 \times 10^{4}$ HLE-B3 cells/well were cultured in six-well plates, digested using $0.25 \%$ trypsin without EDTA and resuspended in $500 \mu \mathrm{l}$ Annexin binding buffer. Subsequently, the cells were incubated with $5 \mu \mathrm{l}$ Annexin V-FITC and $5 \mu \mathrm{l}$ PI in the dark for $15 \mathrm{~min}$. Apoptotic cells were analyzed using a fluorescence-activated cell sorting system (FACSVantage; BD Biosciences) and CellQuest software (version 5.1; BD Biosciences).

Reverse transcription-quantitative PCR. Total RNA was extracted from HLE-B3 cells using TRIzol ${ }^{\circledR}$ reagent (Invitrogen; Thermo Fisher Scientific, Inc.). Total RNA was reverse transcribed into cDNA using a RevertAid RT reverse transcription kit (Invitrogen; Thermo Fisher Scientific, Inc.), incubated at $25^{\circ} \mathrm{C}$ for $5 \mathrm{~min}, 60 \mathrm{~min}$ at $42^{\circ} \mathrm{C}$, then terminated at $70^{\circ} \mathrm{C}$ for $5 \mathrm{~min}$. qPCR was subsequently performed using a SYBR-Green PCR kit (Takara Bio, Inc.). The following thermocycling conditions were used: Initial denaturation at $95^{\circ} \mathrm{C}$ for $10 \mathrm{~min}$, and 35 cycles of $95^{\circ} \mathrm{C}$ for $10 \mathrm{sec}$ and annealing at $60^{\circ} \mathrm{C}$ for $30 \mathrm{sec}$, after which a melting curve analysis was set from $60^{\circ} \mathrm{C}$ to $90^{\circ} \mathrm{C}$. The following primers were used: BCL2 forward, $5^{\prime}$-AACAAATAGTTTATAAAT GTGAA-3' and reverse, 5'-TTCACATTTATAAACTATTTG TT-3'; miR-23a-3p forward, 5'-CCTTTAGGGACCGTTACA CTA-3' and reverse 5'-TAGTGTAACGGTCCCTAAAGG-3'; GAPDH forward, 5'-AAGAAGGTGGTGAAGCAGGC-3' and reverse 5'-GTCAAAGGTGGAGGAGTGGG-3'; and U6 forward, 5'-CTCGCTTCGGCAGCACATA-3' and reverse, 5'-CAGTGCAGGGTCCGAGGTA-3'. The expression levels were quantified using the $2^{-\Delta \Delta C q}$ method (19) and the relative expression levels of BCL2 and miR-23a-3p were normalized to GAPDH and U6, respectively.

Western blotting. Total protein was extracted from HLE-B3 cells using RIPA lysis buffer supplemented with a protein inhibitor cocktail (Roche Applied Science). Protein concentration determination was carried out using a BCA kit (Thermo Fisher Scientific, Inc.). Protein samples (15 $\mu \mathrm{g}$ per lane) were separated via $8 \%$ SDS-PAGE and the separated proteins were transferred onto PVDF membranes. The PVDF membranes were blocked with 5\% non-fat milk at room temperature for $1 \mathrm{~h}$ and then incubated with anti-BCL2 (cat. no. 4223; 1:1,000; Cell Signaling Technology, Inc.), anti-caspase-3 (cat. no. 14220, 1:1,000; Cell Signaling 

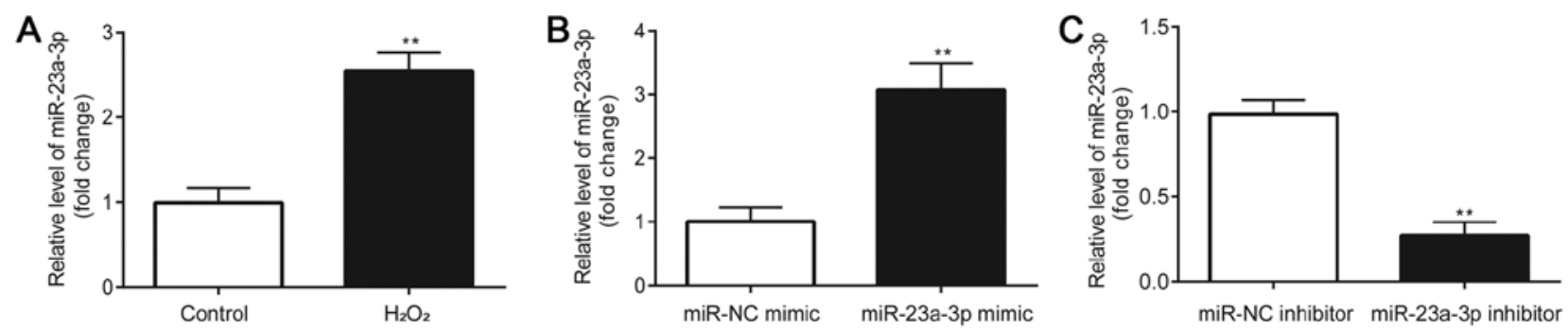

Figure 1. Effects of $\mathrm{H}_{2} \mathrm{O}_{2}$ on miR-23a-3p expression levels in HLE-B3 cells. (A) miR-23a-3p expression the $\mathrm{H}_{2} \mathrm{O}_{2}$ and control groups. miR-23a-3p expression after transfection with (B) miR-23a-3p mimic and (C) miR-23a-3p inhibitor. ${ }^{* * *} \mathrm{P}<0.01$ vs. the respective control group. miR, microRNA; NC, negative control.

Technology, Inc.), anti-caspase-8 (cat. no. 4790; 1:1,000; Cell Signaling Technology, Inc.) and anti-GAPDH (cat. no. 2118; 1:1,000; Cell Signaling Technology, Inc.) primary antibodies overnight at $4^{\circ} \mathrm{C}$. Following the primary antibody incubation, the membranes were incubated with a horseradish peroxidase-conjugated $\operatorname{IgG}$ secondary antibody (cat. no. 5127; 1:2,000; Cell Signaling Technology, Inc.) at room temperature for $2 \mathrm{~h}$. Protein bands were visualized using an ECL chemiluminescence Substrate Reagent kit (Pierce; Thermo Fisher Scientific, Inc.). The densitometry of protein was normalized to GAPDH and analyzed using ImageJ (version 1.5.2; National Institutes of Health).

Statistical analysis. Each experiment was repeated $\geq 3$ times and data are presented as the mean \pm SD. Statistical differences between two groups were analyzed using a two-tailed unpaired Student's t-test, whereas comparisons among three groups were analyzed using one-way ANOVA followed by Newman-Keuls test. $\mathrm{P}<0.05$ was considered to indicate a statistically significant difference.

\section{Results}

MiR-23a-3p expression levels are upregulated in $\mathrm{H}_{2} \mathrm{O}_{2}$-induced HLE-B3 cells. A significant upregulation of miR-23a-3p expression levels was observed in $\mathrm{H}_{2} \mathrm{O}_{2}$-induced HLE-B3 cells compared with the control group (Fig. 1A). Subsequently, the effects of the inhibition of miR-23a-3p expression in $\mathrm{H}_{2} \mathrm{O}_{2}$-induced HLE-B3 cells were investigated. HLE-B3 cells were first transfected with a miR-23a-3p mimic or inhibitor and the transfection efficiency was verified. Compared with the miR-NC mimic group, HLE-B3 cells transfected with the miR-23a-3p mimic had significantly increased miR-23a-3p expression levels (Fig. 1B). Conversely, compared with the miR-NC inhibitor group, HLE-B3 cells transfected with the miR-23a-3p inhibitor had significantly downregulated expression levels of miR-23a-3p (Fig. 1C). These results indicated the successful transfection of the miR-23a-3p mimic or inhibitor into HLE-B3 cells.

Inhibition of miR-23a-3p attenuates the $\mathrm{H}_{2} \mathrm{O}_{2}$-induced decrease in proliferation of HLE-B3 cells. CCK-8 assays were performed to determine the proliferative ability of HLE-B3 cells. Compared with the control group, the proliferative rate of HLE-B3 cells was significantly repressed by $\mathrm{H}_{2} \mathrm{O}_{2}$, which was rescued by the transfection with the miR-23a-3p inhibitor (Fig. 2).

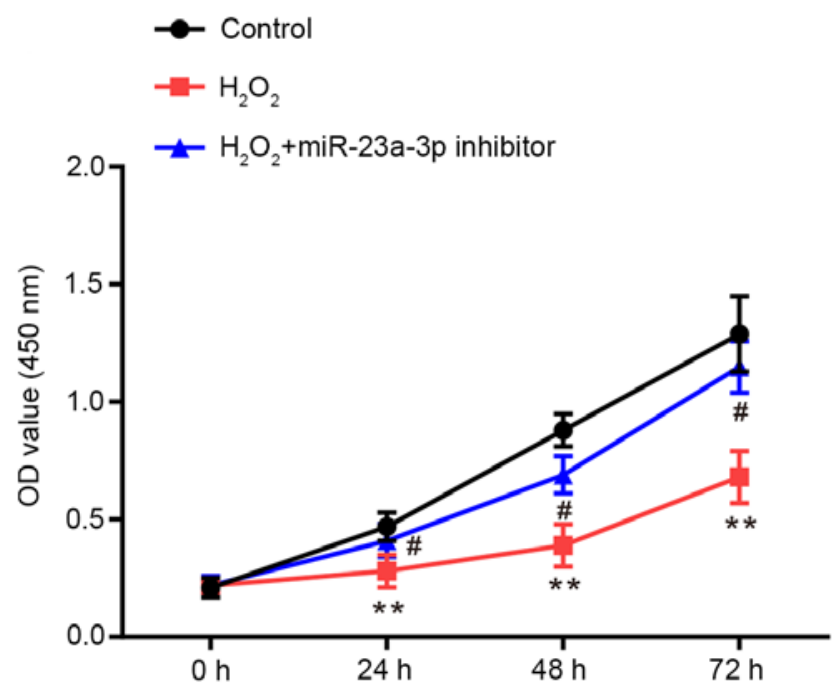

Figure 2. Effects of miR-23a-3p on $\mathrm{H}_{2} \mathrm{O}_{2}$-induced reduction of HLE-B3 cell proliferation. miR-23a-3p inhibitor rescued $\mathrm{H}_{2} \mathrm{O}_{2}$-induced reduction of HLE-B3 cell proliferation. ${ }^{* *} \mathrm{P}<0.01$ vs. the control group and ${ }^{\#} \mathrm{P}<0.05$ vs. the $\mathrm{H}_{2} \mathrm{O}_{2}$ group. miR, microRNA; OD, optical density.

Inhibition of miR-23a-3p attenuates $\mathrm{H}_{2} \mathrm{O}_{2}$-induced apoptosis in HLE-B3 cells. Flow cytometry was performed to determine the levels of apoptosis in HLE-B3 cells. Compared with the control group, HLE-B3 cell apoptosis was significantly induced by $\mathrm{H}_{2} \mathrm{O}_{2}$, which was then attenuated by the transfection with the miR-23a-3p inhibitor (Fig. 3A and B). Taken together, these findings suggested that the miR-23a-3p inhibitor may protect HLE-B3 cells from $\mathrm{H}_{2} \mathrm{O}_{2}$-induced injury.

$B C L 2$ is a target of miR-23a-3p in HLE-B3 cells. Using the online software, TargetScan 7.1, the 3'-UTR of BCL2 was predicted to be complementary to miR-23a-3p (Fig. 4A). A dual luciferase reporter assay was subsequently performed to validate the interaction between miR-23a-3p and BCL2. The results demonstrated that compared with the miR-NC mimic, the miR-23a-3p mimic significantly reduced the relative luciferase activity of the HLE-B3 cells transfected with pGL3-WT-BCL2. However, in HLE-B3 cells transfected with pGL3-MUT-BCL2, no significant differences were observed in the relative luciferase activity between the miR-NC mimic and miR-23a-3p mimic groups (Fig. 4B).

BCL2 expression levels are downregulated in $\mathrm{H}_{2} \mathrm{O}_{2}$-induced HLE-B3 cells. Western blotting was used to analyze BCL2 


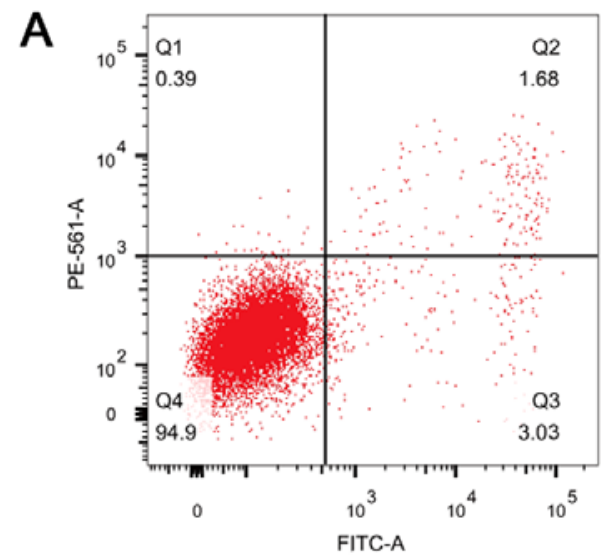

Control

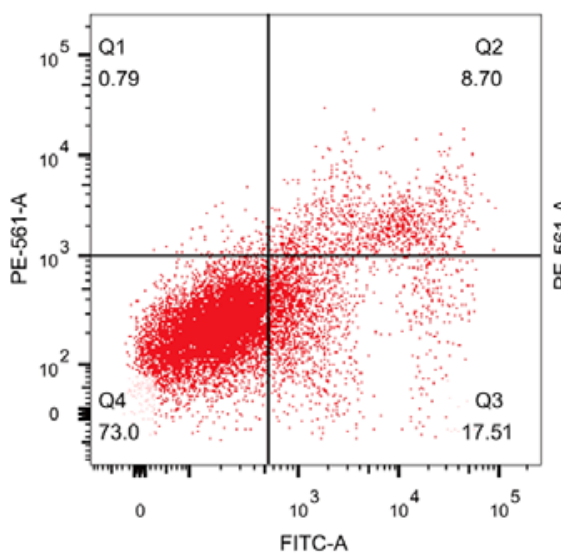

$\mathrm{H}_{2} \mathrm{O}_{2}$

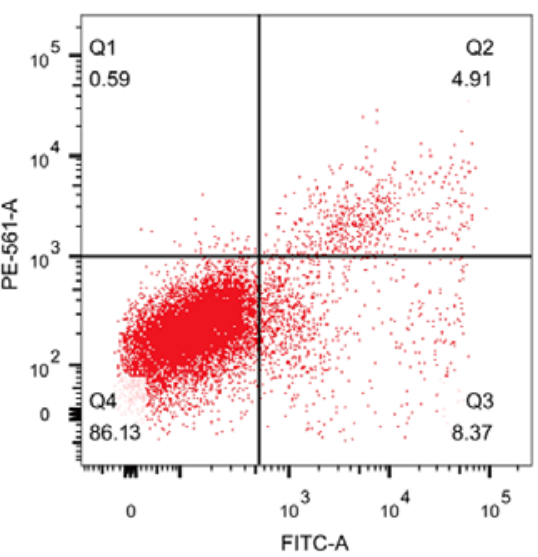

$\mathrm{H}_{2} \mathrm{O}_{2}+$ miR-23a-3p inhibitor

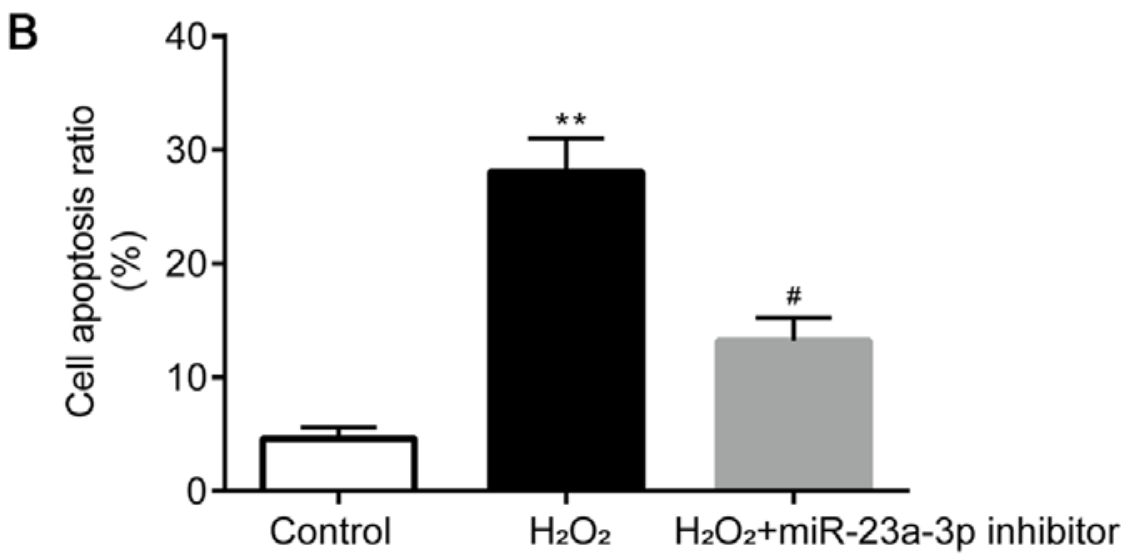

Figure 3. Effects of miR-23a-3p on $\mathrm{H}_{2} \mathrm{O}_{2}$-induced HLE-B3 cell apoptosis. miR-23a-3p inhibitor attenuated $\mathrm{H}_{2} \mathrm{O}_{2}$-induced HLE-B3 cell apoptosis as shown by (A) representative flow cytometry plots and (B) quantitative data analysis. ${ }^{* *} \mathrm{P}<0.01$ vs. the control group and ${ }^{\#} \mathrm{P}<0.05$ vs. the $\mathrm{H}_{2} \mathrm{O}_{2}$ group. miR, microRNA.

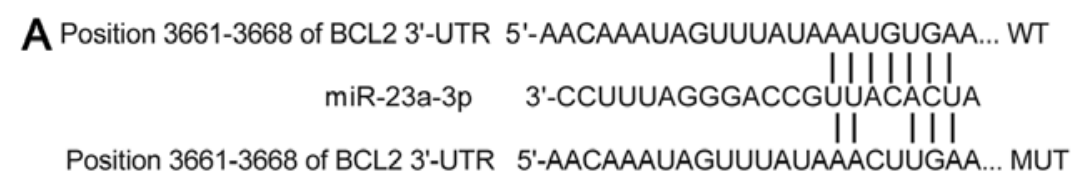

B

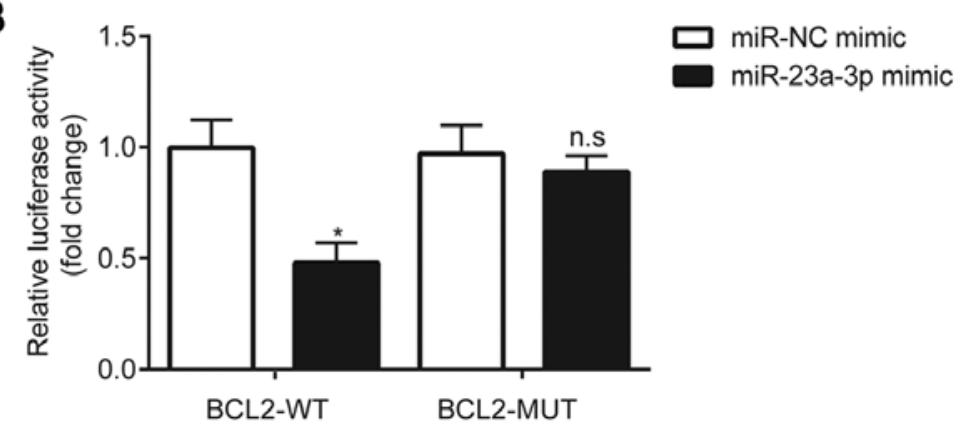

Figure 4. Association between BCL2 and miR-23a-3p in HLE-B3 cells. (A) BCL2 3'-UTR was complementary to miR-23a-3p. (B) miR-23a-3p targeted WT-BCL2 in HLE-B3 cells. "P<0.05 vs. the miR-NC mimic group. n.s, no significant difference; miR, microRNA; NC, negative control; UTR, untranslated region; MUT, mutant; WT, wild-type.

protein expression levels. Compared with the control group, BCL2 protein expression levels were identified to be significantly downregulated in the HLE-B3 cells incubated with $\mathrm{H}_{2} \mathrm{O}_{2}$ (Fig. $5 \mathrm{~A}$ and $\mathrm{B}$ ). 
A
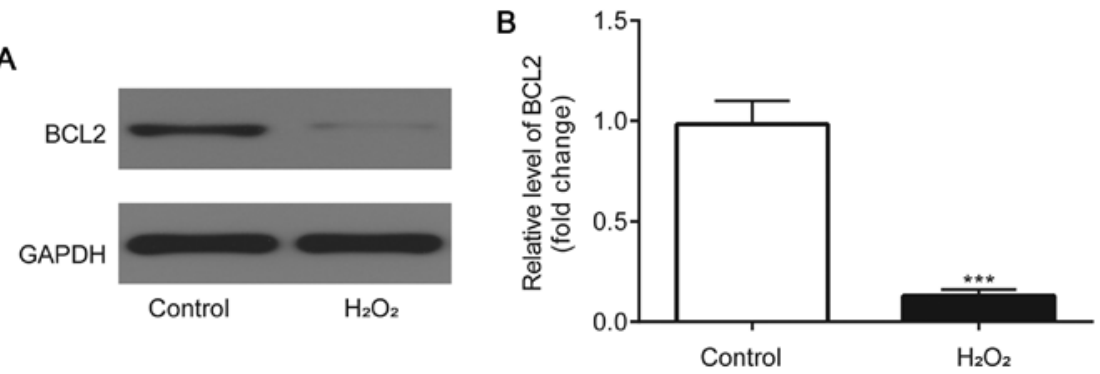

Figure 5. Effects of $\mathrm{H}_{2} \mathrm{O}_{2}$ on BCL2 protein expression levels in HLE-B3 cells. BCL2 protein expression level was significantly decreased in the $\mathrm{H}_{2} \mathrm{O}_{2}$ group as shown by (A) representative blots and (B) semi-quantitative analysis. ${ }^{* * * *} \mathrm{P}<0.001$ vs. the control group.
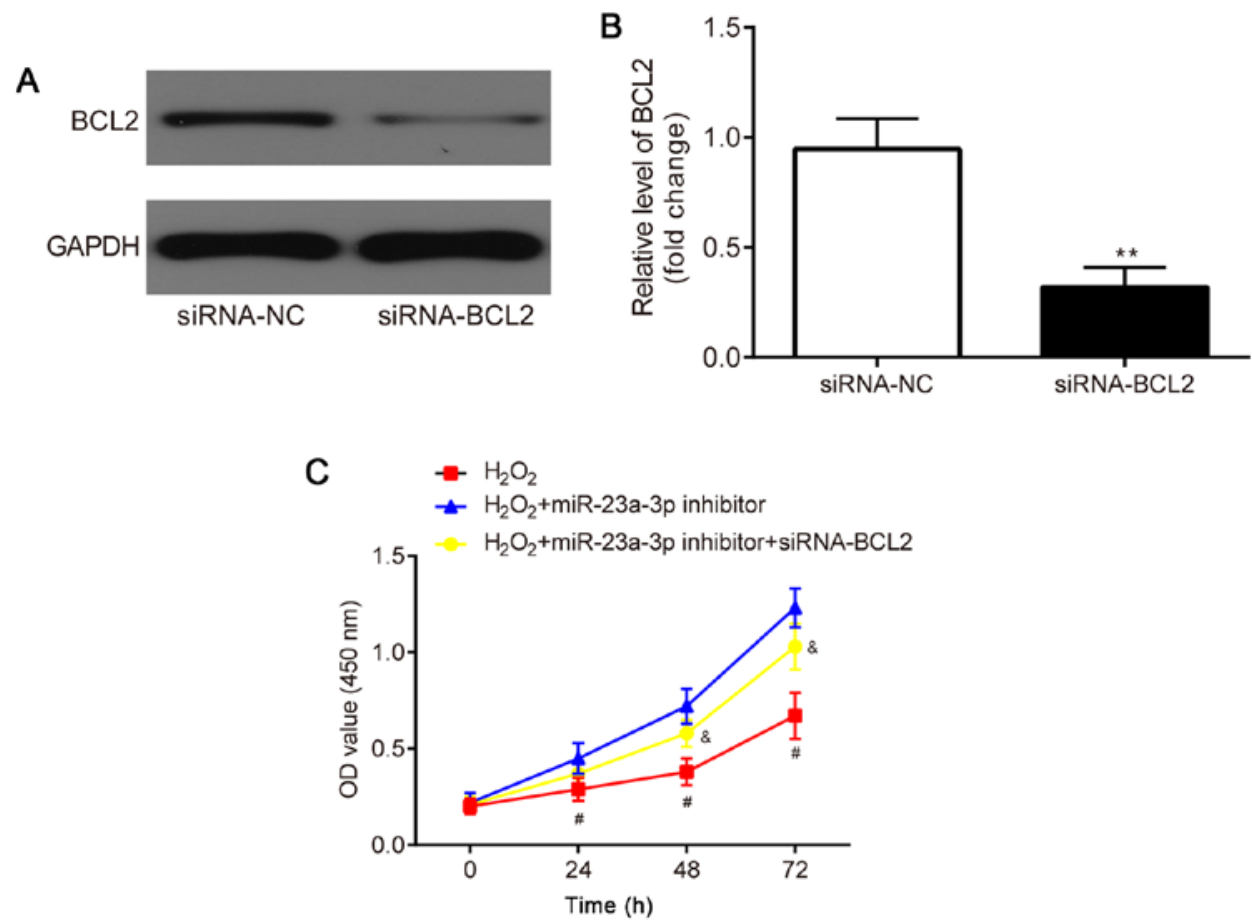

Figure 6. siRNA-BCL2 partially reverses the effects of miR-23a-3p inhibitor on $\mathrm{H}_{2} \mathrm{O}_{2}$-induced reduction in HLE-B3 cell proliferation. (A and B) BCL2 protein expression level was significantly decreased in the siRNA-BCL2 group. (C) siRNA-BCL2 partially abolished miR-23a-3p inhibitor-induced upregulation of HLE-B3 cell proliferation. *" $\mathrm{P}<0.01$ vs. the siRNA-NC group, ${ }^{\text {}} \mathrm{P}<0.05$ vs. the $\mathrm{H}_{2} \mathrm{O}_{2}+$ miR-23a-3p inhibitor group. ${ }^{\text {\& }} \mathrm{P}<0.05$ vs. the $\mathrm{H}_{2} \mathrm{O}_{2}+$ miR-23a-3p inhibitor group. NC, negative control; siRNA, small interfering RNA; miR, microRNA; OD, optical density.

miR-23a-3p inhibitor attenuates the $\mathrm{H}_{2} \mathrm{O}_{2}$-induced reduction of proliferation of HLE-B3 cells by targeting BCL2. The effects of the co-transfection of siRNA-BCL2 and miR-23a-3p inhibitor in $\mathrm{H}_{2} \mathrm{O}_{2}$-induced HLE-B3 cells were subsequently investigated. HLE-B3 cells were first transfected with siRNA-NC or siRNA-BCL2 to verify the transfection efficacy. The results revealed that compared with the siRNA-NC group, the protein expression levels of BCL2 were significantly downregulated in the siRNA-BCL2 group (Fig. 6A and B).

A CCK-8 assay was performed to determine the proliferative ability of the HLE-B3 cells. Compared with the $\mathrm{H}_{2} \mathrm{O}_{2}$ group, the miR-23a-3p inhibitor increased the proliferation of the HLE-B3 cells, which was subsequently partially reversed through the co-transfection with siRNA-BCL2 (Fig. 6C).

miR-23a-3p inhibitor attenuates $\mathrm{H}_{2} \mathrm{O}_{2}$-induced apoptosis in HLE-B3 cells by targeting BCL2. Flow cytometric analysis was used to analyze the levels of apoptosis in HLE-B3 cells.
The levels of HLE-B3 cell apoptosis were decreased following the transfection with the miR-23a-3p inhibitor compared with the $\mathrm{H}_{2} \mathrm{O}_{2}$ group, which was then partially reversed by the co-transfection with siRNA-BCL2 (Fig. 7A and B).

Western blotting was used to analyze caspase- 3 and caspase- 8 protein expression levels. Caspase- 3 and caspase- 8 protein expression levels were identified to be significantly downregulated in the HLE-B3 cells following the transfection with the miR-23a-3p inhibitor compared with the $\mathrm{H}_{2} \mathrm{O}_{2}$ group, which was then partially reversed by the co-transfection with siRNA-BCL2 (Fig. 8A and B).

\section{Discussion}

Previous microarray analysis reported the dysregulation of multiple miRNAs in cataractous lenses, including miR-23a (16); however, to the best of our knowledge, the exact function of miR-23a-3p in cataracts remains undetermined. 
A
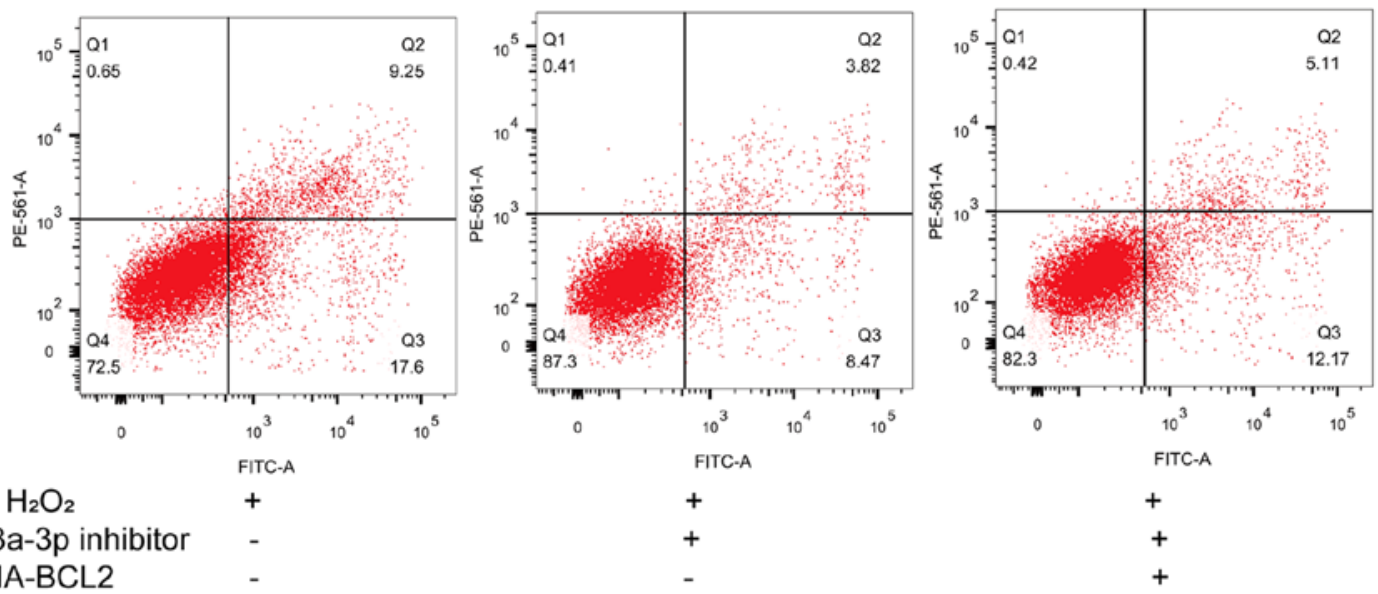

B

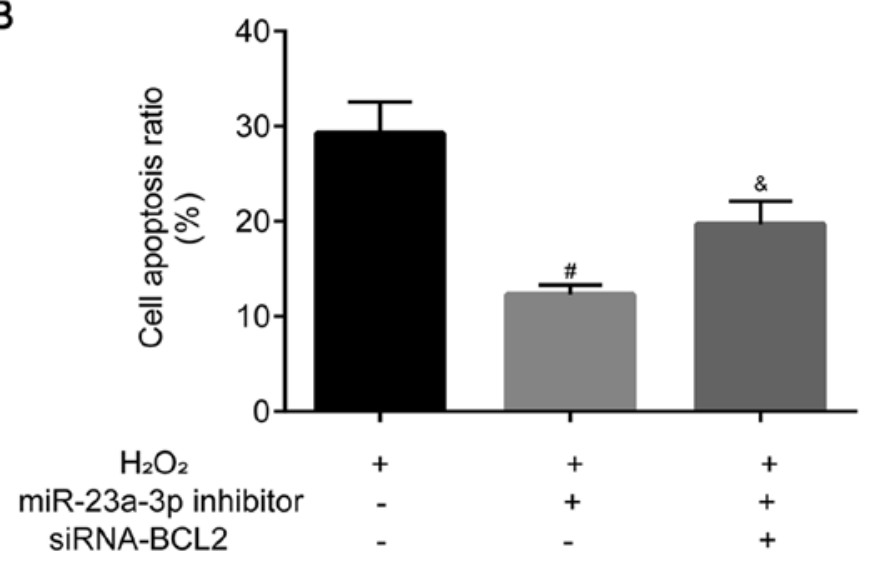

Figure 7. siRNA-BCL2 partially reverses the effects of miR-23a-3p inhibitor on $\mathrm{H}_{2} \mathrm{O}_{2}$-induced HLE-B3 cell apoptosis. siRNA-BCL2 partially abolished miR-23a-3p inhibitor-induced downregulation of HLE-B3 cell apoptosis as shown by (A) representative flow cytometry plots and (B) quantitative data analysis. ${ }^{\#} \mathrm{P}<0.05$ vs. the $\mathrm{H}_{2} \mathrm{O}_{2}$ group and ${ }^{\&} \mathrm{P}<0.05$ vs. the $\mathrm{H}_{2} \mathrm{O}_{2}+$ miR-23a-3p inhibitor group. siRNA, small interfering RNA; miR, microRNA.

A

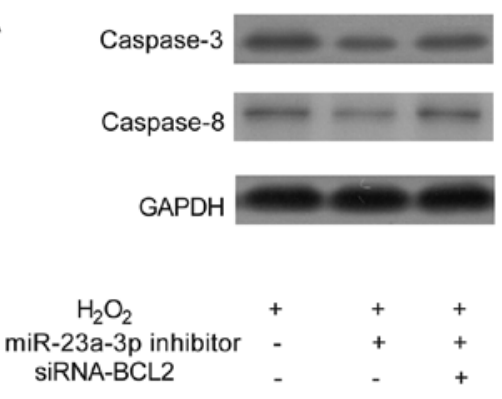

B

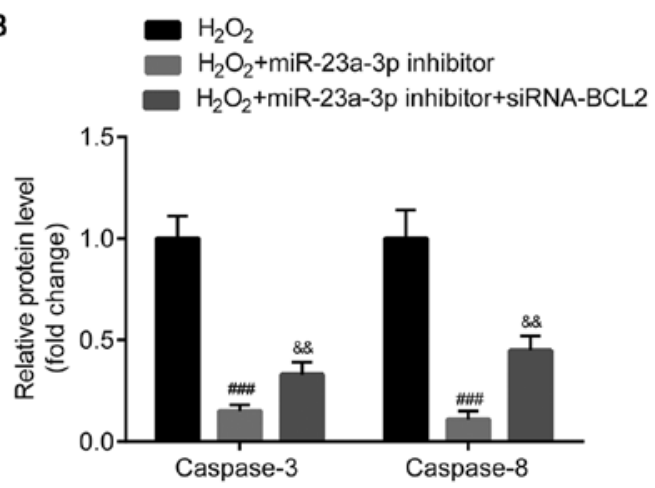

Figure 8. siRNA-BCL2 partially reverses the effects of miR-23a-3p inhibitor on $\mathrm{H}_{2} \mathrm{O}_{2}$-induced protein expression of caspase-3 and caspase-8. siRNA-BCL2 partially abolished miR-23a-3p inhibitor-induced downregulation of caspase-3 and caspase-8 in HLE-B3 cells as shown by (A) representative blots and (B) semi-quantitative analysis. ${ }^{\# \#} \mathrm{P}<0.001$ vs. the $\mathrm{H}_{2} \mathrm{O}_{2}$ group and ${ }^{\&} \& \mathrm{P}<0.01$ vs. $\mathrm{H}_{2} \mathrm{O}_{2}+$ miR-23a-3p inhibitor group. siRNA, small interfering RNA; miR, microRNA.

Oxidants have been shown to induce apoptosis and result in the development of cataracts (10). Therefore, to establish an in vitro cataract model in the present study, HLE-B3 cells were induced with $\mathrm{H}_{2} \mathrm{O}_{2}$, as described in a previous study $(17,18)$. miR-23a-3p expression levels were revealed to be upregulated in $\mathrm{H}_{2} \mathrm{O}_{2}$-induced HLE-B3 cells, which suggested the potential involvement of miR-23a-3p in cataract development and provided further evidence for the role of miR-23a-3p in cataracts, as previously reported (16).

The apoptosis of LECs, which is induced by oxidative stress, is a cellular mechanism frequently occurring in cataracts (20). Accumulating evidence suggests the involvement of miRNAs in the apoptosis of LECs; for example, in cataracts, miR-let-7b promoted LEC apoptosis by targeting leucine-rich repeat 
containing $\mathrm{G}$ protein-coupled receptor 4 (21); miR-378a was shown to increase LEC apoptosis by targeting the superoxide dismutase 1 gene (22); and miR-26a and miR-26b reduced lens fibrosis by regulating the Jagged-1/Notch signaling pathway (23). The present study demonstrated that the inhibition of miR-23a-3p expression levels reduced the $\mathrm{H}_{2} \mathrm{O}_{2}$-induced apoptosis of HLE-B3 cells. However, to the best of our knowledge, the potential target mRNAs of miR-23a-3p remained to be investigated.

In the present study, miR-23a-3p was predicted and verified to target BCL2, an anti-apoptotic gene family member, in HLE-B3 cells, which may improve the current understanding of the role of miR-23a-3p in numerous types of human disease $(24,25)$. In a previous study, BCL2 reduced cell apoptosis by acting via cellular signal transduction pathways or inhibiting lipid oxidation via inhibition of oxygen free radicals (26). BCL2 protein expression level was lower in the lens epithelium of elderly individuals compared with that of human fetuses and children (27). BCL2 was reported to be associated with cell apoptosis in oxidative stress-induced cataracts; for example, BCL2 protein expression levels were reduced in LECs if cell apoptosis was induced (28), and anthocyanin was shown to protect HLECs against oxidative damage and prevent the $\mathrm{H}_{2} \mathrm{O}_{2}$-induced downregulation of BCL2 (29). In addition, the downregulation of Smac expression levels attenuated the $\mathrm{H}_{2} \mathrm{O}_{2}$-induced apoptosis and downregulation of BCL2 expression levels in HLECs (30). Furthermore, ELL-associated factor 2 prevented HLECs from oxidative stress-induced apoptosis and the downregulation of BCL2 expression levels by targeting the Wnt signaling pathway (31). Previously, the 3'-UTR of BCL2 was discovered to be targeted by several miRNAs in cataracts. For example, miR-34a induced HLEC apoptosis by targeting BCL2 (32) and miR-15a-3p repressed the proliferation and promoted the apoptosis of HLECs by targeting BCL2 $(17,33)$. However, to the best of our knowledge, whether miR-23a-3p can regulate the formation of cataracts by targeting BCL2 remained undetermined. In the present study, BCL2 protein expression levels were significantly downregulated in $\mathrm{H}_{2} \mathrm{O}_{2}$-induced HLE-B3 cells. In addition, the miR-23a-3p inhibitor was found to attenuate $\mathrm{H}_{2} \mathrm{O}_{2}$-induced apoptosis and the inhibition of proliferation in HLE-B3 cells by targeting BCL2. However, the present study was an in vitro investigation, which suggested that targeting BCL2 may be useful for treating cataracts; therefore, further in vivo studies are required to confirm these findings.

Caspase- 3 and caspase- 8 were previously demonstrated to be positively associated with the apoptosis of HLECs $(34,35)$. Therefore, the protein expression levels of caspase- 3 and caspase- 8 were also evaluated in the present study. The results revealed that caspase- 3 and caspase- 8 protein expression levels were downregulated following the transfection with the miR-23a-3p inhibitor compared with the $\mathrm{H}_{2} \mathrm{O}_{2}$ group; however, the downregulated expression levels were reversed following the transfection with siRNA-BCL2.

In conclusion, the findings of the present study indicated that the inhibition of miR-23a-3p expression levels may attenuate $\mathrm{H}_{2} \mathrm{O}_{2}$-induced injury of human lens epithelial cells by targeting $\mathrm{Bcl}-2$ in an in vitro model of cataract by targeting BCL2, thus providing a novel therapeutic target for the treatment of patients with cataracts.

\section{Acknowledgements}

Not applicable.

\section{Funding}

No funding was received.

\section{Availability of data and materials}

The datasets used and/or analyzed during the current study are available from the corresponding author on reasonable request.

\section{Authors' contributions}

PY conceived the study, performed the experiments and analyzed the data. XM analyzed the data. JJ, ZC, YH and YW performed the experiments and analyzed the data. All authors read and approved the final manuscript.

\section{Ethics approval and consent to participate}

Not applicable.

\section{Patient consent for publication}

Not applicable.

\section{Competing interests}

The authors declare that they have no competing interests.

\section{References}

1. Lee CM and Afshari NA: The global state of cataract blindness. Curr Opin Ophthalmol 28: 98-103, 2017.

2. Liu YC, Wilkins M, Kim T, Malyugin B and Mehta JS: Cataracts. Lancet 390: 600-612, 2017.

3. Khairallah M, Kahloun R, Bourne R, Limburg H, Flaxman SR, Jonas JB, Keeffe J, Leasher J, Naidoo K, Pesudovs K, et al: Number of people blind or visually impaired by cataract worldwide and in world regions, 1990 to 2010. Invest Ophthalmol Vis Sci 56: 6762-6769, 2015 .

4. Hodge WG, Whitcher JP and Satariano W: Risk factors for age-related cataracts. Epidemiol Rev 17: 336-346, 1995.

5. Kempen JH, Sugar EA, Varma R, Dunn JP, Heinemann MH, Jabs DA, Lyon AT and Lewis RA; Studies of Ocular Complications of AIDS Research Group: Risk of cataract among subjects with acquired immune deficiency syndrome free of ocular opportunistic infections. Ophthalmology 121: 2317-2324, 2014.

6. Keel S and He M: Risk factors for age-related cataract. Clin Exp Ophthalmol 46: 327-328, 2018.

7. Jiang H, Yin Y, Wu CR, Liu Y, Guo F, Li M and Ma L: Dietary vitamin and carotenoid intake and risk of age-related cataract. Am J Clin Nutr 109: 43-54, 2019.

8. Kim B, Kim SY and Chung SK: Changes in apoptosis factors in lens epithelial cells of cataract patients with diabetes mellitus. J Cataract Rcfract Surg 38: 1376-1381, 2012.

9. Yan Q, Liu JP and Li DW: Apoptosis in lens development and pathology. Differentiation 74: 195-211, 2006.

10. Li WC, Kuszak JR, Dunn K, Wang RR, Ma W, Wang GM, Spector A, Leib M, Cotliar AM, Weiss M, et al: Lens epithelial cell apoptosis appears to be a common cellular basis for non-congenital cataract development in humans and animals. J Cell Biol 130: 169-181, 1995.

11. Kim VN: MicroRNA biogenesis: Coordinated cropping and dicing. Nat Rev Mol Cell Biol 6: 376-385, 2005.

12. Bartel DP: MicroRNAs: Genomics, biogenesis, mechanism, and function. Cell 116: 281-297, 2004. 
13. Ambros V: The functions of animal microRNAs. Nature 431: 350-355, 2004.

14. Gong W, Li J, Wang Y, Meng J and Zheng G: miR-221 promotes lens epithelial cells apoptosis through interacting with SIRT1 and E2F3. Chem Biol Interact 306: 39-46, 2019.

15. Zhou W, Xu J, Wang C, Shi D and Yan Q: miR-23b-3p regulates apoptosis and autophagy via suppressing SIRT1 in lens epithelial cells. J Cell Biochem 120: 19635-19646, 2019.

16. Wu C, Lin H, Wang Q, Chen W, Luo H, Chen W and Zhang H: Discrepant expression of microRNAs in transparent and cataractous human lenses. Invest Ophthalmol Vis Sci 53: 3906-3912, 2012.

17. Li Q, Pan H and Liu Q: MicroRNA-15a modulates lens epithelial cells apoptosis and proliferation through targeting B-cell lymphoma-2 and E2F transcription factor 3 in age-related cataracts. Biosci Rep 39: BSR20191773, 2019.

18. Ren H, Tao H, Gao Q, Shen W, Niu Z, Zhang J, Mao H, Du A and $\mathrm{Li} \mathrm{W}$ : miR-326 antagomir delays the progression of age-related cataract by upregulating FGF1-mediated expression of betaB2-crystallin. Biochem Biophys Res Commun 505: $505-510,2018$

19. Livak KJ and Schmittgen TD: Analysis of relative gene expression data using real-time quantitative PCR and the 2(-Delta Delta C(T)) method. Methods 25: 402-408, 2001.

20. Zhang ZF, Zhang J, Hui YN, Zheng MH, Liu XP, Kador PF, Wang YS, Yao LB and Zhou J: Up-regulation of NDRG2 in senescent lens epithelial cells contributes to age-related cataract in human. PLoS One 6: e26102, 2011.

21. Dong Y, Zheng Y, Xiao J, Zhu C and Zhao M: MicroRNA let-7b induces lens epithelial cell apoptosis by targeting leucine-rich repeat containing $\mathrm{G}$ protein-coupled receptor $4(\mathrm{Lgr} 4)$ in age-related cataract. Exp Eye Res 147: 98-104, 2016.

22. Liu Y, Li HH and Liu Y: microRNA-378a regulates the reactive oxygen species (ROS)/Phosphatidylinositol 3-Kinases (PI3K)/AKT signaling pathway in human lens epithelial cells and cataract. Med Sci Monit 25: 4314-4321, 2019.

23. Chen X, Xiao W, Chen W, Liu X, Wu M, Bo Q, Luo Y, Ye S, Cao Y and Liu Y: MicroRNA-26a and -26b inhibit lens fibrosis and cataract by negatively regulating Jagged-1/Notch signaling pathway. Cell Death Differ 24: 1431-1442, 2017.

24. Thomadaki $\mathrm{H}$ and Scorilas A: BCL2 family of apoptosis-related genes: Functions and clinical implications in cancer. Crit Rev Clin Lab Sci 43: 1-67, 2006.

25. Vogler M, Walter HS and Dyer MJS: Targeting anti-apoptotic BCL2 family proteins in haematological malignancies-from pathogenesis to treatment. Br J Haematol 178: 364-379, 2017.
26. Frenzel A, Grespi F, Chmelewskij W and Villunger A: Bcl2 family proteins in carcinogenesis and the treatment of cancer. Apoptosis 14: 584-596, 2009.

27. Weng $\mathbf{J}$ and Zhang H: The characteristics of bcl-2 and PCNA expression in the lens epithelium of human being. Zhonghua Yan Ke Za Zhi 37: 197-199, 2001 (In Chinese).

28. Yu Y, Xing K, Badamas R, Kuszynski CA, Wu H and Lou MF: Overexpression of thioredoxin-binding protein 2 increases oxidation sensitivity and apoptosis in human lens epithelial cells. Free Radic Biol Med 57: 92-104, 2013.

29. Mok JW, Chang DJ and Joo CK: Antiapoptotic effects of anthocyanin from the seed coat of black soybean against oxidative damage of human lens epithelial cell induced by $\mathrm{H}_{2} \mathrm{O}_{2}$. Curr Eye Res 39: 1090-1098, 2014.

30. Kong DQ, Liu Y, Li L and Zheng GY: Downregulation of Smac attenuates $\mathrm{H}_{2} \mathrm{O}_{2}$-induced apoptosis via endoplasmic reticulum stress in human lens epithelial cells. Medicine (Baltimore) 96: e7419, 2017.

31. Feng K and Guo HK: Eaf2 protects human lens epithelial cells against oxidative stress-induced apoptosis by Wnt signaling. Mol Med Rep 17: 2795-2802, 2018.

32. Li QL, Zhang HY, Qin YJ, Meng QL, Yao XL and Guo HK: MicroRNA-34a promoting apoptosis of human lens epithelial cells through down-regulation of B-cell lymphoma-2 and silent information regulator. Int J Ophthalmol 9: 1555-1560, 2016.

33. Liu SJ, Wang WT, Zhang FL, Yu YH, Yu HJ, Liang Y, Li N and Li YB: miR-15a-3p affects the proliferation, migration and apoptosis of lens epithelial cells. Mol Med Rep 19: 1110-1116, 2019.

34. Ma T, Chen T, Li P, Ye Z, Zhai W, Jia L, Chen W, Sun A, Huang Y, Wei S and Li Z: Heme oxygenase-1 (HO-1) protects human lens epithelial cells (SRA01/04) against hydrogen peroxide $\left(\mathrm{H}_{2} \mathrm{O}_{2}\right)$-induced oxidative stress and apoptosis. Exp Eye Res 146: 318-329, 2016.

35. Sundararajan M, Thomas PA, Teresa PA, Anbukkarasi M and Geraldine P: Regulatory effect of chrysin on expression of lenticular calcium transporters, calpains, and apoptotic-cascade components in selenite-induced cataract. Mol Vis 22: 401-423, 2016.

This work is licensed under a Creative Commons Attribution-NonCommercial-NoDerivatives 4.0 International (CC BY-NC-ND 4.0) License. 